\title{
CCAT2, a novel long non-coding RNA in breast cancer: expression study and clinical correlations
}

\author{
Roxana S Redis ${ }^{1,3, *}$, Anieta M Sieuwerts ${ }^{2, *}$, Maxime P Look ${ }^{2}$, Oana Tudoran ${ }^{4}$, Cristina \\ Ivan $^{6}$, Riccardo Spizzo${ }^{5}$ Xinna Zhang ${ }^{6}$, Vanja de Weerd ${ }^{2}$, Masayoshi Shimizu ${ }^{1}$, Hui \\ Ling $^{1}$, Rares Buiga ${ }^{10}$, Victor Pop ${ }^{3}$, Alexandru Irimie ${ }^{11}$, Riccardo Fodde ${ }^{7}$, Isabella \\ Bedrosian $^{8}$, John WM Martens ${ }^{2}$, John A Foekens ${ }^{2}$, Ioana Berindan-Neagoe ${ }^{4,9}$, \\ George A Calin ${ }^{1,7}$ \\ ${ }^{1}$ Department of Experimental Therapeutics, The University of Texas MD Anderson Cancer Center, Houston, Texas, USA. \\ 2 Department of Medical Oncology, Erasmus MC Cancer Institute, Erasmus University Medical, Rotterdam, The Netherlands \\ ${ }^{3}$ Department of Molecular Science, University of Medicine and Pharmacy Iuliu Hatieganu, Cluj-Napoca, Romania. \\ ${ }^{4}$ Department of Functional Genomics, The Oncology Institute, Cluj-Napoca, Romania. \\ ${ }^{5}$ Division of Experimental Oncology, CRO, National Cancer Institute, Aviano, Italy. \\ ${ }^{6}$ Center for RNA Interference and Non-coding RNAs The University of Texas MD Anderson Cancer Center, Houston, Texas, \\ USA. \\ 7 Department of Pathology, Josephine Nefkens Institute, Erasmus Medical Center, Rotterdam, The Netherlands. \\ 8 Department of Surgical Oncology, The University of Texas MD Anderson Cancer Center, Houston, Texas, USA. \\ ${ }^{9}$ Research Center for Functional Genomics, Biomedicine and Translational Medicine, University of Medicine and Pharmacy \\ Iuliu Hatieganu, Cluj-Napoca, Romania. \\ ${ }^{10}$ Department of Pathology, The Oncology Institute, Cluj-Napoca, Romania \\ 11 Department of Surgical and Gynecology Oncology, University of Medicine and Pharmacy Iuliu Hatieganu, Cluj-Napoca, \\ Romania. \\ * These authors contributed equally to this work \\ Correspondence to: George A. Calin, email: gcalin@mdanderson.org
}

loana Berindan-Neagoe, email: ioana.neagoe@umfcluj.com

Keywords: non coding RNA, CCAT2, breast cancer, prognosis, real-time PCR.

Received: August 15, $2013 \quad$ Accepted: September 16, $2013 \quad$ Published: September 18, 2013

This is an open-access article distributed under the terms of the Creative Commons Attribution License, which permits unrestricted use, distribution, and reproduction in any medium, provided the original author and source are credited.

ABSTRACT:

The clinical outcome of BC patients receiving the same treatment is known to vary considerably and thus, there is a compelling need to identify novel biomarkers that can select the patients that would benefit most from a given therapy and can predict the clinical outcome. The aim of this study was to determine the prognostic value of CCAT2, a novel long ncRNA recently characterized by our group and overlapping SNP rs6983267, in BC patients. We first evaluated by RT-qPCR and ISH the expression of CCAT2 in normal breast tissue and BC tissue and further analyzed CCAT2 expression in an independent set of 997 primary BC with regard to clinical, histological, pathological and other biological factors. Also, we explored the possibility of CCAT2 adding to the prognostic value of multivariate models that already included the traditional prognostic factors. Finally, we identified in in vitro models the impact of CCAT2 expression and SNP rs6983267 genotype on cell migration and chemoresistance. Our results revealed that although overexpressed in BCs in two out of three sets of patients, and having the highest expression in lymph node negative (LNN) disease, CCAT2 expression levels are informative solely for a subgroup of BC patients, namely for patients with LNP disease that have received adjuvant CMF chemotherapy. For this subgroup high levels of CCAT2 suggest the patients will not benefit from CMF containing adjuvant chemotherapy (shorter MFS and OS). Additionally, we found that CCAT2 upregulates cell migration and downregulates chemosensitivity to $5^{\prime} \mathrm{FU}$ in a rs6983267-independent manner. 


\section{INTRODUCTION}

Evidence is rapidly accumulating that, in addition to short microRNAs, long non-coding RNAs (lncRNAs, transcripts of at least $200 \mathrm{nt}$ long that do not code for proteins but regulate expression of coding genes) are involved in human tumorigenesis. Their ability to regulate essential pathways for tumor initiation and progression together with their tissue and stage specificity, promotes them as valuable biomarkers and therapeutic targets [1-5]. In an earlier study our group demonstrated that a large fraction of genomic ultraconserved regions (UCRs) encode a particular set of ncRNAs, named transcribed UCRs (T-UCRs) whose expression is altered in human cancers [6]. Genome-wide profiling revealed that T-UCRs have distinct signatures in human leukemias and carcinomas and they are frequently located at fragile sites and genomic regions involved in cancers. Our findings argued that ncRNAs are involved in tumorigenesis to a greater extent than previously thought. This offers the prospect of defining tumor-specific signatures of ncRNAs that are associated with diagnosis, prognosis, and response to treatment.

Chromosomal copy number aberrations (CNAs) are common in breast cancer (BC) and involve genomic regions in a frequency and combination that suggest distinct routes of tumor development. Patterns of copy number gains and losses define breast tumors with distinct clinico-pathological features and patient prognosis $[7,8]$. For example, the 5-year survival rates varied from $96 \%$ in a group of BCs defined by $+1 \mathrm{q},+16 \mathrm{p}$, and $-16 \mathrm{q}$ to $56 \%$ in a group of BCs defined by $-8 p$ and $+8 q$. These correlations were independent of nodal status, tumor size, and progesterone receptor (PR) status in a multivariate analysis [9]. Furthermore, amplification of $8 \mathrm{q} 24$ genomic region was observed more frequently in invasive solidtubular or scirrhous tumors $(48 / 92,52 \%)$ than in less aggressive histological types $(7 / 25,28 \%)$ [10]. In another study results suggested that there was a relationship between 8q24 DNA amplification profiles and breast tumor phenotype [11]. Thus, amplification of oncogene(s) located on 8q24 may play a role in the development and/or progression of a substantial proportion of primary breast cancers, particularly those of the invasive histology, but the nature of this/these genes is yet unknown.

We have recently reported the discovery of a novel long ncRNA, CCAT2 (Colon $\underline{\text { Cancer }} \underline{\mathrm{A} s s o c i a t e d}$ Transcript 2) transcribed from $8 \mathrm{q} 24$ genomic region [12]. The CCAT2 genomic locus similar to UCRs is highly conserved and harbors the SNP rs6983267, which was shown to be associated with predisposition to colon, ovarian and prostate cancer [13-18] and more recently with risk of metastasis in inflammatory BC [19]. CCAT2 promotes metastasis and chromosomal instability in microsatellite stable (MSS) colon cancer through a mechanism involving transcription factors, oncogenes and microRNAs [12].
In light of these findings and previous reports, we hypothesized that CCAT2 may be overexpressed in $\mathrm{BC}$ and act as an oncogene inducing a metastatic phenotype. To investigate this hypothesis, we evaluated the expression of CCAT2 in non-cancer and $\mathrm{BC}$ tissues and, in a large independent set of primary tumors the related expression with clinical, histological, pathological and other biological factors. Moreover, we tested expression levels of CCAT2 in multivariate models that already included the traditional prognostic factors. Finally, we expanded our study to include in vitro models, in which we evaluated the impact of CCAT2 expression and the SNP rs6983267 on cell migration and chemoresistance.

\section{RESULTS}

\section{CCAT2 is expressed in breast tumors}

While focusing on the genomic characterization of CCAT2 novel long non-coding RNA, the Northern Blot data showed that it is expressed also in $\mathrm{BC}$ cell lines (Supplementary Fig. 1). We further measured the RNA expression levels of CCAT2 by RT-qPCR in a set of 56 unmatched samples (26 non-cancer breast tissues and 30 breast cancer tissues) from OICN and detected significantly increased levels of CCAT2 RNA in tumor samples compared to the non-tumor group $(P=0.026)$ (Fig. 1a).

To further explore this result and identify the tissue localization of CCAT2, we performed in situ hybridization (ISH) employing a locked-nucleic acid (LNA) specific probe for the IncRNA on tissue microarray (TMA), containing 16 non-tumor samples and 18 tumor samples from MDACC. Notably, these patients were not subjected to neo-adjuvant chemotherapy. All the samples, both tumor and non-tumor tissues, showed a strong staining of CCAT2 in epithelial cells and a less intense staining in inflammatory and stromal cells. CCAT2 appeared to have higher expression in the epithelial component of BC tissue than in epithelial component of non-tumor tissue $(P<0.001)$ (Fig. 1b). Moreover, expression was detected in invasive epithelial components, as well as in "in situ" epithelial lesions, with no visible differences between the two components of cancers (Supplementary Fig. 2a, b). Apocrine metaplasia, columnar metaplasia and the usual intraductal epithelial hyperplasia disclosed a similar pattern of CCAT2 expression as the non-tumor breast tissue (Supplementary Fig. 2c). The ISH assay allowed also for the assessment of the subcellular localization of CCAT2, expression was detected in both the nucleus and the cytoplasm, with a more intense staining of the nucleus, indicating an obvious enrichment of CCAT2 in the nuclear compartment (Supplementary Fig. 2d).

However, in a different set of 15 unpaired normal 
1 a.

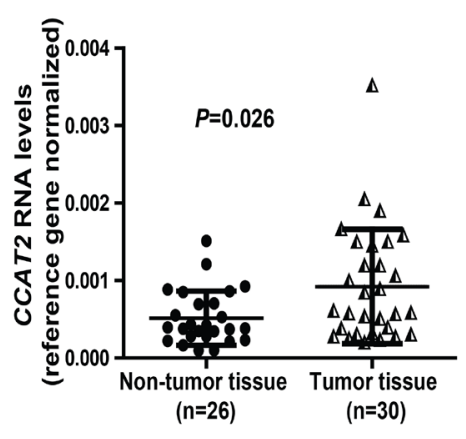

1c.
$1 \mathrm{~b}$.

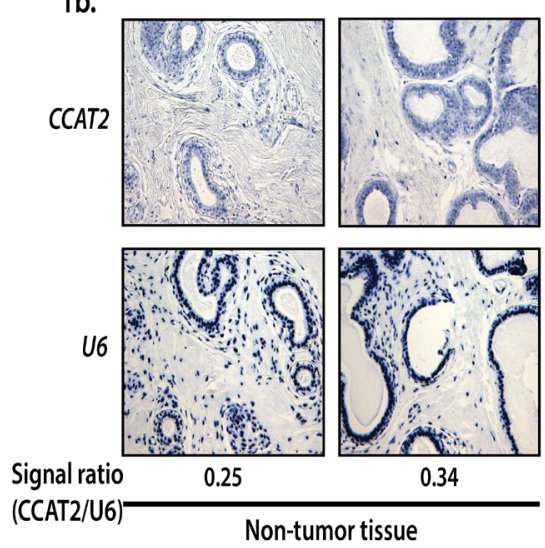

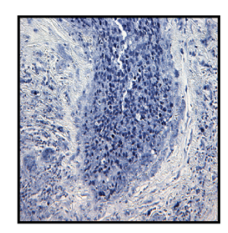
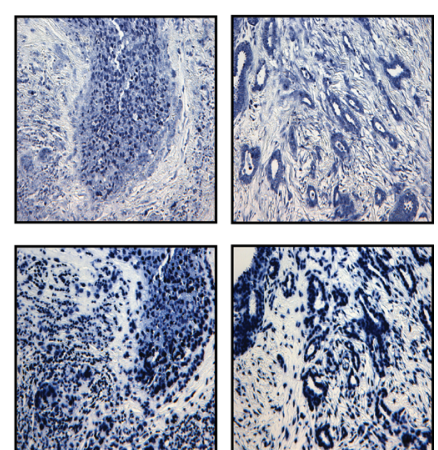

0.63

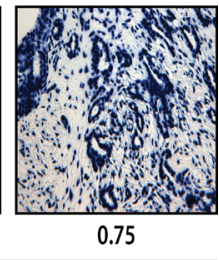

Tumor tissue

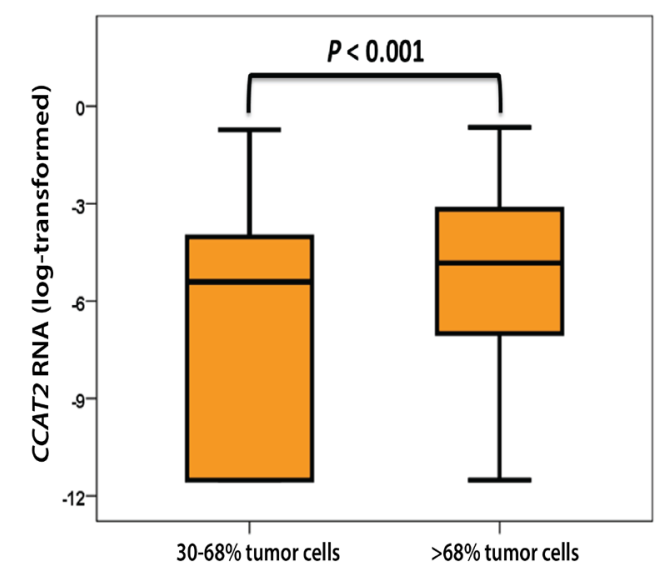

1d.

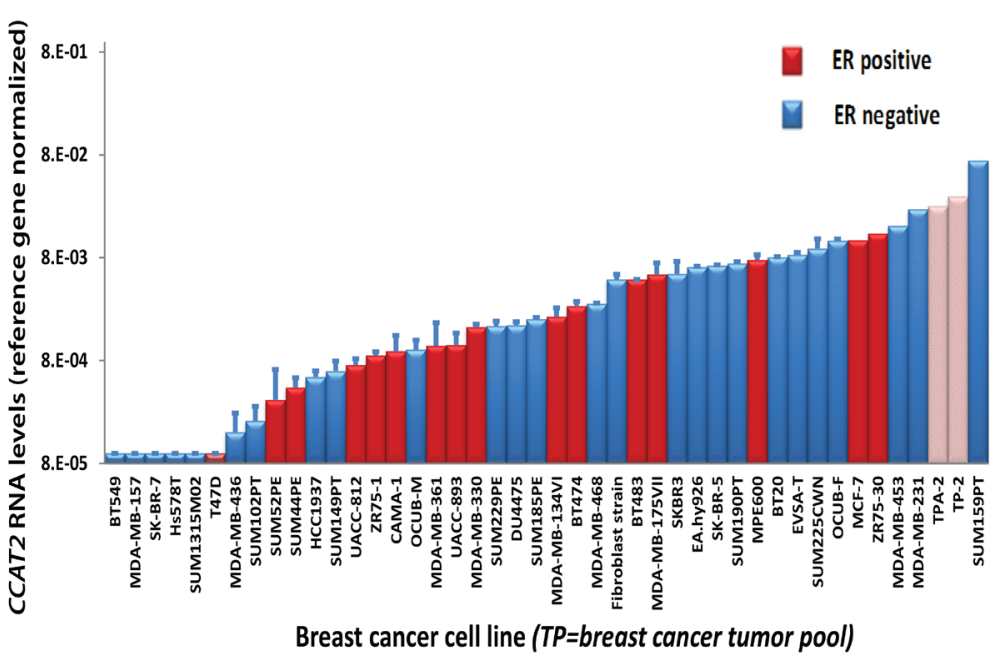

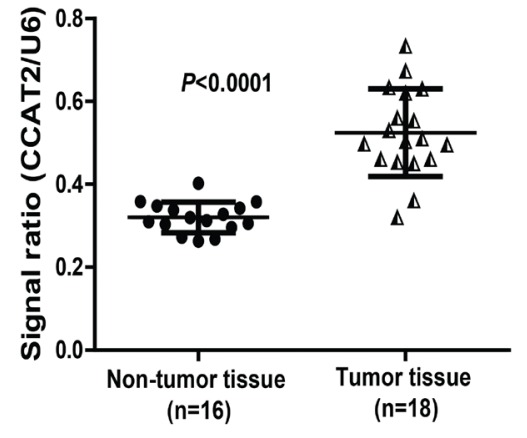

1e.

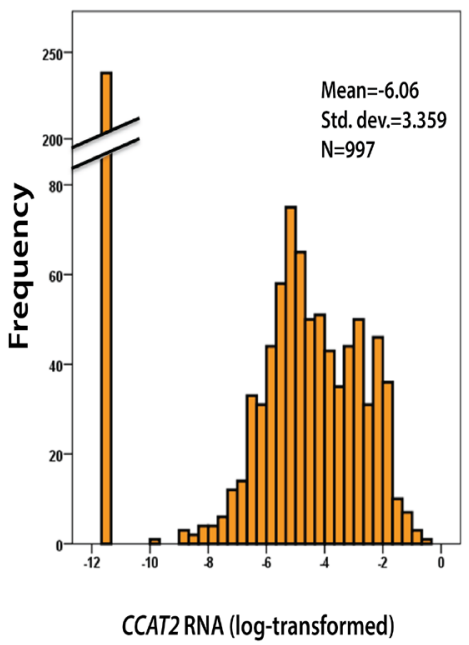

Figure 1: a) CCAT2 expression in BC patients (OICN cohort) quantified by qRT-PCR. b). In situ hybridization of CCAT2 and U6 (as reference) in $\mathrm{BC}$ patient samples and CCAT2 expression in BC patients determined by quantifying ISH images from TMA slide. Each sample was represented in 5 replicates for non-cancer tissue and 3 replicates for cancer tissue on the slide. c). Expression of CCAT2 mRNA in clinical breast cancers (EMC cohort) after dividing the cancers at the median level in tumors containing a relatively high percentage $(>68 \%)$ of invasive tumor cells and tumors containing a relatively low percentage (30-68\%) of invasive tumor cells (RT-qPCR mRNA levels expressed as fold difference relative to the 3-gene reference gene set). d). Expression levels of CCAT2 mRNA in human breast cancer cell lines and 2 pools of breast cancers (TP-2 and TPA-2, hatched bars) (RT-qPCR mRNA levels expressed as fold difference relative to the 3-gene reference gene set). e) Distribution of CCAT2 mRNA in clinical breast cancers (RT-qPCR levels expressed relative to the 3-gene reference gene set). 
breast tissues from EMC, CCAT2 expression levels measured by RT-qPCR did not vary significantly from the levels measured in the $\mathrm{n}=977$ clinical specimens (CCAT2 RNA levels in normal and tumor tissue, average \pm SD: $0.0078 \pm 0.00445$ and $0.0060 \pm 0.00298$, respectively, $P>0.05)$. Although, after dividing the tumors at the median in groups containing a low $(n=492,30-68 \%)$ or high $(n=505,>68 \%)$ percentage of invasive tumor cells,

$2 a$.

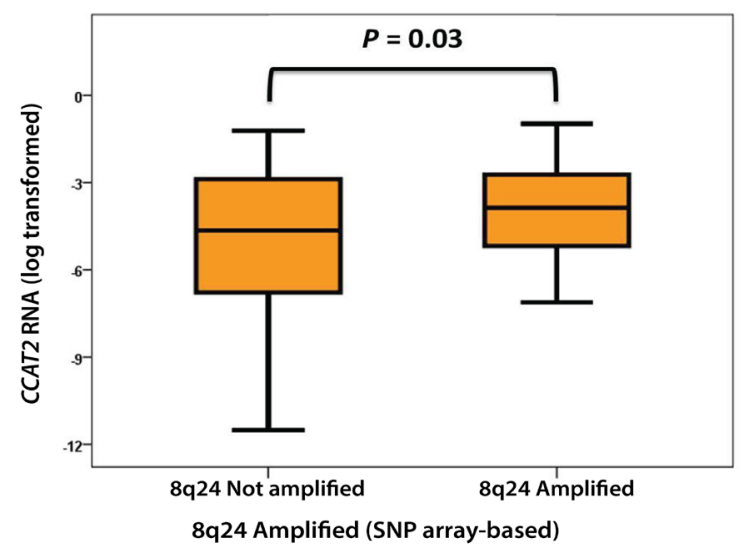

$2 b$.

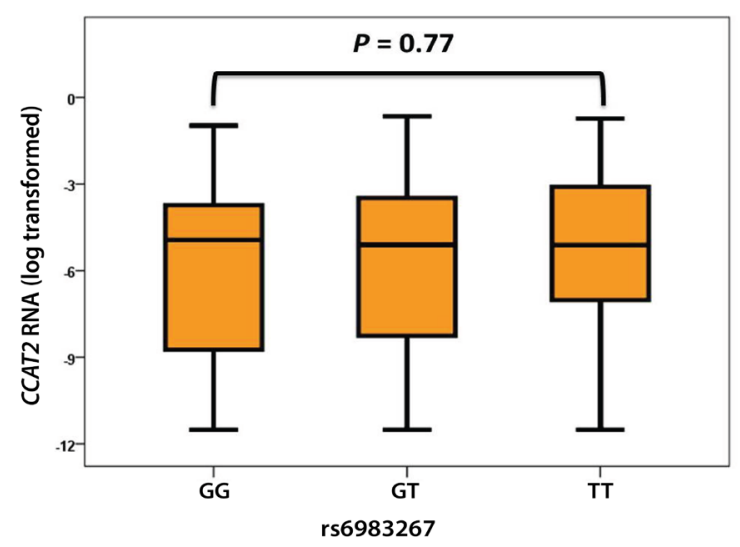

2c.

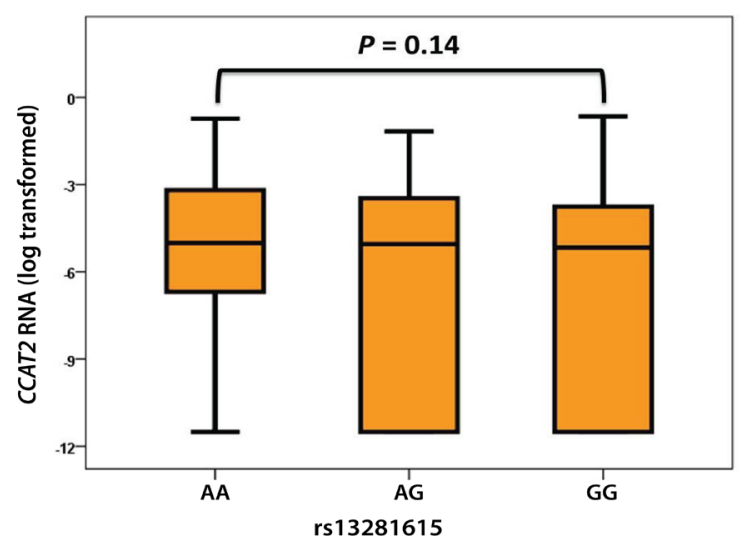

Figure 2: Associations of $C C A T 2$ with a) amplification of $8 q 24$ ( $n=80$ amplified versus $n=146$ unamplified) and the SNPs b) $\operatorname{rs6983267}(n=241$ GG, n=393 GT, $n=238$ TT) and c) $\operatorname{rs13281615}(n=297 \mathrm{AA}, \mathrm{n}=392 \mathrm{AG}$, n=157 GG).
CCAT2 RNA levels were significantly higher in the group of tumors with high invasive tumor cells (MannWhitney U Test, $P<0.001$ ) (Fig 1c). Therefore, additional larger studies are needed to assess the levels of CCAT2 in breast tumors versus normal tissues in multiple patient populations.

Additionally, we assessed CCAT2 expression in a set of cultured breast cell lines, showing a wide range of expression levels with the expression measured in 2 different pools of BCs tissues located in the upper range (hatched bars, Fig. 1d). Correspondingly to our observation in cultured cell lines (Fig. 1d, 6 out of 40, $15 \%$ ), levels of CCAT2 were undetectable within 35 amplification rounds in 238 out of 997 (24\%) of the primary breast tumors from the EMC patient set (Fig. 1e). This patient set of CCAT2 expressers was further used for investigating the correlations between CCAT2 and clinical, histo-morphological and biological characteristics.

\section{Associations of CCAT2 with relevant biological factors, amplification of $8 \mathrm{q} 24$ and the SNPs rs6983267 and rs13281615}

To investigate whether there is an association of CCAT2 expression levels with well-established biological factors, we matched our CCAT2 expression data with those of ESR1, PGR, ERBB2, and the proliferation marker $K i-67$ measured in the same preparations (EMC patient set). In addition, we used our SNP data to associate CCAT2 transcript levels in $226 \mathrm{LNN}$ patients with known DNA copy number to identify tumor samples with copy number alterations that showed concordant CCAT2 gene expression alterations. In these clinical samples, increasing levels of ESRI and $P G R$ associated significantly with decreasing levels of CCAT2 (Spearman $r_{s}=-0.14$ and -0.13, respectively, $\mathrm{n}=997, P<0.001)$, although $C C A T 2$ was not significantly $(P=0.79)$ associated with $E R B B 2$ (Mann-Whitney U test for amplified vs. unamplified $E R B B 2$ ) or $K i-67$ (Spearman $\left.r_{\mathrm{s}}=0.022, \mathrm{n}=988, P=0.50\right)$. As expected due to the genomic location, a positive association with amplification of the 8q24 region was observed ( $P=0.03$ in Mann-Whitney $U$ test with 80 out of 226 samples amplified in the $8 \mathrm{q} 24$ region covering the $C C A T 2$ gene) (Fig. 2a). Increasing levels of $M Y C$, also located on $8 \mathrm{q} 24$, were positively associated with $C C A T 2$ (Spearman $r_{s}=0.11, \mathrm{n}=992, P<0.001$ ).

Next, we investigated whether there is an association between the expression levels of CCAT2 and SNP rs6983267. We measured CCAT2 expression and genotyped 872 of our primary breast tumor samples, but did not find a significant correlation (Fig. 2b). It must be however mentioned that in this clinical $\mathrm{BC}$ cohort there was a significant deviation from the Hardy-Weinberg equilibrium (HWE $P=0.004$ ) possibly implying a selection bias. Of note that in this cohort there was also 
Table 1: Associations of CCAT2 expression levels with clinical, biological and histomorphological factors.

\section{Characteristic}

All patients in this cohort

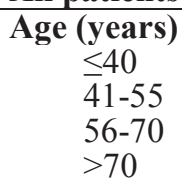

Menopausal status premenopausal postmenopausal

ER mRNA status ${ }^{\ddagger}$ negative, $<0.2$ positive, $\geq 0.2$

PR mRNA status ${ }^{\ddagger}$ negative, $<0.1$ positive, $\geq 0.1$

Grade

poor unknown Moderate/good

Tumor size

pT1, $\leq 2 \mathrm{~cm}$

pT2, $>2-5 \mathrm{~cm}+$ unknown

pT $3,>5 \mathrm{~cm}+$ pT 4

Lymph nodes involved no, (LNN) yes, (LNP), 1 to 3 yes, (LNP), $>3$

Histological type ${ }^{\top}$

IDC

DCIS + IDC

ILC

mucinous

\begin{tabular}{|c|c|c|c|}
\hline \multicolumn{4}{|c|}{ All patients } \\
\hline 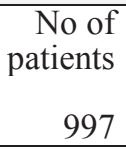 & $\begin{array}{r}\% \\
100 \% \\
\end{array}$ & $\begin{array}{r}\boldsymbol{C C} \\
\text { median } \\
0.61 \\
\end{array}$ & $\begin{array}{c}\text { T2 RNA }\left(\times 10^{-2}\right) \\
\text { inter-quartile } \\
2.98 \\
\end{array}$ \\
\hline $\begin{array}{l}140 \\
394 \\
313 \\
150\end{array}$ & $\begin{array}{l}14 \% \\
40 \% \\
31 \% \\
15 \%\end{array}$ & $\begin{array}{r}0.69 \\
0.57 \\
0.56 \\
0.77 \\
P=0.19\end{array}$ & $\begin{array}{l}5.12 \\
3.07 \\
2.36 \\
2.82\end{array}$ \\
\hline $\begin{array}{l}460 \\
537\end{array}$ & $\begin{array}{l}46 \% \\
54 \%\end{array}$ & $\begin{array}{r}0.61 \\
0.59 \\
P=0.06^{8}\end{array}$ & $\begin{array}{l}3.69 \\
2.40\end{array}$ \\
\hline $\begin{array}{l}230 \\
767\end{array}$ & $\begin{array}{l}23 \% \\
77 \%\end{array}$ & $\begin{array}{r}1.19 \\
0.54 \\
P<0.001\end{array}$ & $\begin{array}{l}4.78 \\
2.16\end{array}$ \\
\hline $\begin{array}{l}396 \\
601\end{array}$ & $\begin{array}{l}40 \% \\
60 \%\end{array}$ & $\begin{array}{r}0.83 \\
0.49 \\
\boldsymbol{P}<\mathbf{0 . 0 0 1}^{\mp}\end{array}$ & $\begin{array}{l}4.09 \\
2.24\end{array}$ \\
\hline $\begin{array}{l}531 \\
282 \\
184\end{array}$ & $\begin{array}{l}53 \% \\
28 \% \\
18 \%\end{array}$ & $\begin{array}{r}0.65 \\
0.56 \\
0.57 \\
P=0.38^{\|}\end{array}$ & $\begin{array}{l}3.44 \\
2.41 \\
2.44\end{array}$ \\
\hline $\begin{array}{r}377 \\
534 \\
86\end{array}$ & $\begin{array}{r}38 \% \\
54 \% \\
9 \%\end{array}$ & $\begin{array}{r}0.57 \\
0.64 \\
0.52 \\
P=0.24^{\|}\end{array}$ & $\begin{array}{l}2.20 \\
3.46 \\
2.59\end{array}$ \\
\hline $\begin{array}{l}621 \\
189 \\
187\end{array}$ & $\begin{array}{l}62 \% \\
19 \% \\
19 \%\end{array}$ & $\begin{array}{r}0.84 \\
0.40 \\
0.45 \\
P<\mathbf{0 . 0 0 1}\end{array}$ & $\begin{array}{l}4.60 \\
1.24 \\
1.11\end{array}$ \\
\hline $\begin{array}{r}533 \\
151 \\
85 \\
29\end{array}$ & $\begin{array}{r}53 \% \\
15 \% \\
9 \% \\
3 \%\end{array}$ & $\begin{array}{r}0.56 \\
0.50 \\
0.61 \\
0.47 \\
P=0.50 \\
\end{array}$ & $\begin{array}{l}2.39 \\
1.97 \\
3.58 \\
1.27\end{array}$ \\
\hline
\end{tabular}

$\neq \quad$ ER + and/or PR+ with RT-PCR cut point used for ER, 0.2 and PR, 0.1 (relative to reference gene set). Only data for the 4 most common histological subtypes are presented in this table,

IDC; infiltrating ductal carcinoma, DCIS; ductal carcinoma in situ, ILC; infiltrating lobular carcinoma.

* Due to missing data numbers do not add up to 997.

$+\quad P$ for Spearman rank correlation test.

$\S \quad P$ for Mann-Whitney U test.

\|I $\quad P$ for Kruskal-Wallis test, including a Wilcoxon-type test for trend when appropriate.

no significant correlation for CCAT2 and the different genotypes of SNP rs13281615. This SNP, for which our measurements did not result in a deviation from the Hardy-Weinberg equilibrium (HWE $P=0.17$ ), is also located in the 8q24 region, approximately $10 \mathrm{~kb}$ upstream of CCAT2 and the SNP rs6983267, and has previously been associated with increased $\mathrm{BC}$ risk $[13,20]$ (Fig. 2c).

\section{Associations of CCAT2 RNA with clinical and histo-morphological factors and risk to develop a distant metastasis}

Correlations of RNA expression of CCAT2 with patient and tumor characteristics are shown in Table 
Table 2: CCAT2 expression levels in Cox univariate analysis for distant metastasis-free and overall survival.

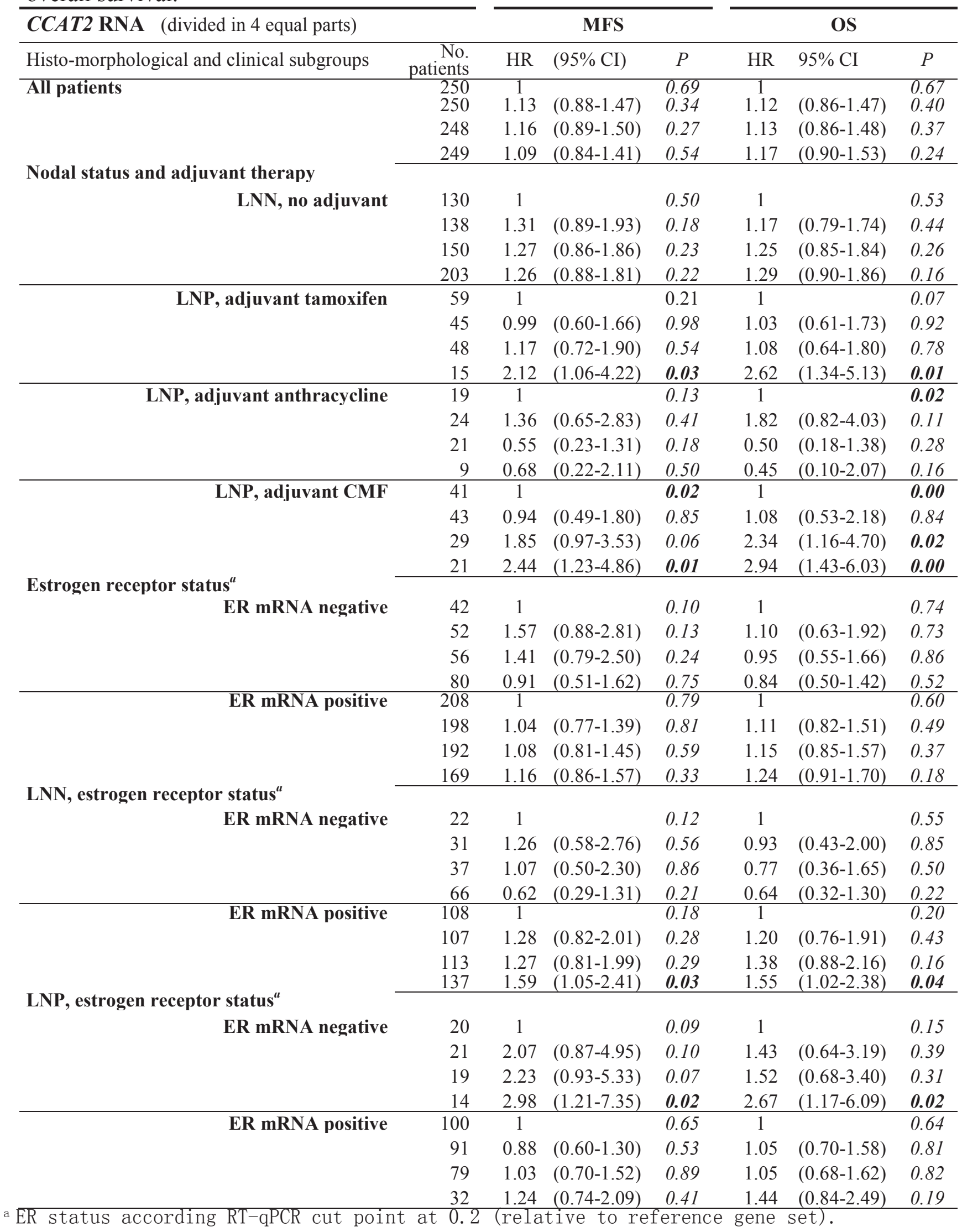


Table 3: Cox univariate and multivariate analysis for MFS as a function of CCAT2 in primary breast tumors from $134 \mathrm{LNP}$ breast tumor patients that received adjuvant $\mathrm{CMF}^{a}$

\begin{tabular}{|c|c|c|c|c|c|c|c|}
\hline \multirow[b]{2}{*}{ Factor } & \multirow[b]{2}{*}{$\begin{array}{l}\text { No. } \\
\text { patients }\end{array}$} & \multicolumn{3}{|c|}{ Univariate analysis } & \multicolumn{3}{|c|}{ Multivariate analysis } \\
\hline & & HR & $95 \% \mathrm{CI}$ & $P$ & HR & $95 \% \mathrm{CI}$ & $P$ \\
\hline & & & & & \multicolumn{3}{|c|}{ Base model } \\
\hline \multicolumn{8}{|l|}{ Age at start of therapy, years } \\
\hline$\leq 40$ & 35 & 1 & & & 1 & & \\
\hline$>40$ & 99 & 0.74 & $(0.44-1.25)$ & 0.260 & 0.73 & $(0.43-1.26)$ & 0.259 \\
\hline \multicolumn{8}{|c|}{ Menopausal status at start of therapy } \\
\hline premenopausal & 119 & 1 & & & 1 & & \\
\hline postmenopausal & 15 & 1.15 & $(0.57-2.32)$ & 0.700 & 1.40 & $(0.63-3.08)$ & 0.410 \\
\hline \multicolumn{8}{|l|}{ Tumor size } \\
\hline $\mathrm{pT} 1, \leq 2 \mathrm{~cm}$ & 36 & 1 & & & 1 & & \\
\hline $\mathrm{pT} 2,>2-\leq 5 \mathrm{~cm}$ & 80 & 1.92 & $(1.03-3.56)$ & 0.039 & 1.73 & $(0.92-3.23)$ & 0.087 \\
\hline $\mathrm{pT} 3,>5 \mathrm{~cm},+\mathrm{pT} 4$ & 18 & 2.82 & $(1.28-6.20)$ & 0.010 & 3.42 & $(1.49-7.87)$ & 0.004 \\
\hline \multicolumn{8}{|l|}{ Lymph nodes involved } \\
\hline $1-3$ & 92 & 1 & & & 1 & & \\
\hline$>3$ & 42 & 1.62 & $(0.99-2.62)$ & 0.052 & 1.58 & $(0.96-2.59)$ & 0.069 \\
\hline \multicolumn{8}{|l|}{ Grade } \\
\hline poor & 70 & 1 & & & 1 & & \\
\hline unknown & 42 & 0.60 & $(0.34-1.04)$ & 0.066 & 0.48 & $(0.26-0.87)$ & 0.016 \\
\hline moderate & 22 & 0.46 & $(0.22-0.96)$ & 0.039 & 0.46 & $(0.21-0.98)$ & 0.044 \\
\hline \multicolumn{8}{|l|}{ ER status, mRNA level ${ }^{c}$} \\
\hline negative, $<0.2$ & 25 & 1 & & & 1 & & \\
\hline positive, $\geq 0.2$ & 109 & 0.77 & $(0.42-1.40)$ & 0.390 & 0.63 & $(0.28-1.42)$ & 0.265 \\
\hline \multicolumn{8}{|l|}{ PR status, mRNA level ${ }^{c}$} \\
\hline negative, $<0.1$ & 45 & 1 & & & 1 & & \\
\hline positive, $\geq 0.1$ & 89 & 0.97 & $(0.59-1.60)$ & 0.910 & 1.48 & $(0.73-2.99)$ & 0.273 \\
\hline & & & & \multicolumn{4}{|c|}{ Additions to the base model $^{b}$} \\
\hline \multicolumn{8}{|l|}{ CCAT2 RNA level } \\
\hline $0-25 \%$ & 41 & 1 & & & 1 & & \\
\hline $25-50 \%$ & 43 & 0.94 & $(0.49-1.80)$ & 0.846 & 0.98 & $(0.50-1.93)$ & 0.960 \\
\hline $50-75 \%$ & 29 & 1.85 & $(0.97-3.53)$ & 0.063 & 1.94 & $(0.98-3.85)$ & 0.056 \\
\hline $75-100 \%$ & 21 & 2.44 & $(1.23-4.86)$ & 0.011 & 2.25 & $(1.07-4.74)$ & 0.033 \\
\hline
\end{tabular}

\footnotetext{
${ }^{a}$ Seven of these patients received both hormonal therapy and chemotherapy and one patient had a ovarectomy.

${ }^{b}$ CCAT2 RNA levels were separately introduced to the base multivariate model that included the following factors: age, menopausal status, nodal status, pathological tumor size, grade, ER and PR status.

${ }^{c}$ ER and PR status according RT-qPCR cut point at 0.2 for ER and 0.1 for PR (mRNA levels relative to reference gene set).
}

1. Most notable were the strong inverse associations of CCAT2 expression levels with nodal status $(P<0.001)$ and hormone (ER and PR) receptor status $(P<0.001)$.

Within our evaluation of the possible relationship of CCAT2 levels with prognosis we proceeded with performing exploratory Cox univariate analyses for metastases-free survival (MFS) and overall survival (OS) as a function of CCAT2 RNA levels (divided in 4 equally sized groups based on the quartile levels of all 997 tumors) in the clinically relevant subgroups of LNN, LNP, ER+, and ER-patients, groups in which we already observed a divergent CCAT2 expression (Table 2). Moreover, because all patients with LNP disease received systemic adjuvant therapy, we divided these patients according to the adjuvant therapy they had received. Results are summarized in Table 2. Despite the higher expression of CCAT2 in tumors of the LNN vs. the LNP patient cohort, there was no significant association with prognosis in 
3a.

MDA-MB-231
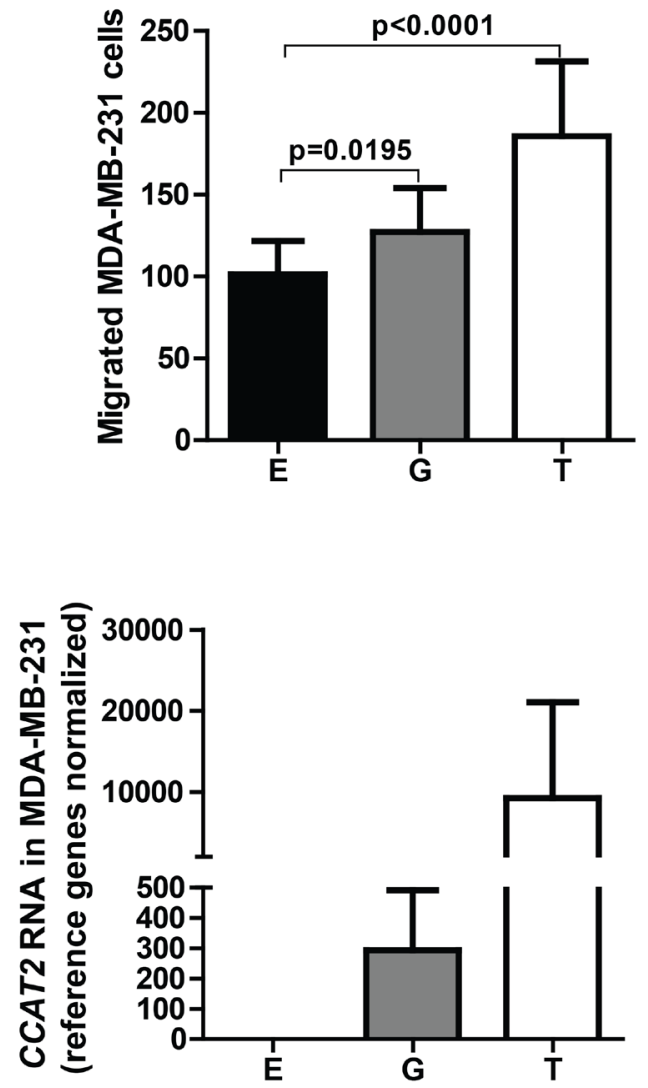

$3 b$.

MDA-MB-436
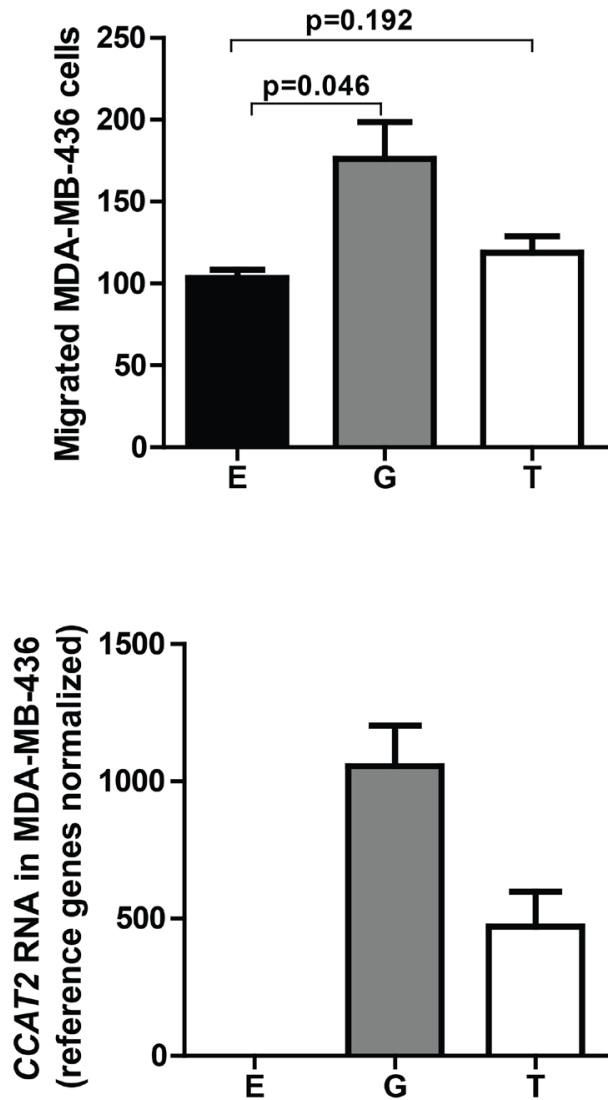

3c.

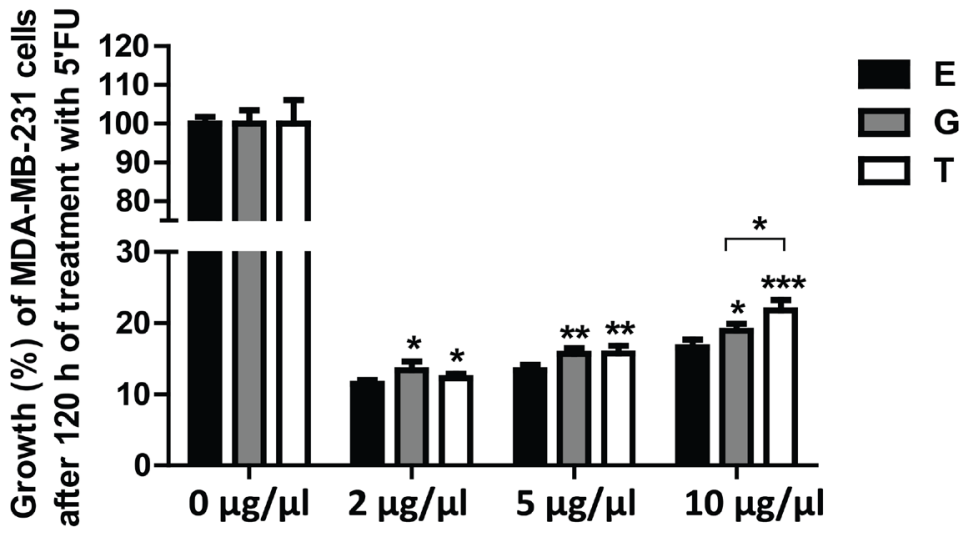

Figure 3: a). (Upper panel) Migration of MDA-MB-231 cells stably transfected with the empty vector (E), and vectors containing the CCAT2 G, T alleles. Results represent the mean value of 3 experiments performed in triplicate $\pm \mathrm{SD}$. (Lower panel) CCAT2 expression levels in the MDA-MB-231 clones assessed by RT-qPCR (U6 and HPRT1 were used as reference genes). b). (Upper panel) Migration of MDA-MB-436 cells transiently transfected with pcDNA CCAT2 vectors. Results represent the mean value of 3 experiments performed in triplicate $\pm \mathrm{SD}$. (Lower panel) CCAT2 expression levels in the MDA-MB-436 cells assessed 24 hours after transient transfection with pcDNA CCAT2 vectors by qRT-PCR qPCR (U6 and HPRT1 were used as reference genes). c). Effect of 5'Fluorouracil (5'FU) on cell proliferation of MDA-MB-231 CCAT2 clones (E, G, T). Cells were treated with 3 different concentrations of 5'FU and after 120 hours and the cell viability was determined by the MTT assay. Results represent the mean value of 2 experiments performed in quadruplicate \pm SD. Statistical significance is marked with the star symbol, namely ‘*’ for $P<0.05$, ‘**' for $P<0.001$ and '***' for $P<0.0001$. 
these patients who had not received systemic adjuvant therapy, neither in the ER-negative subgroup, nor in the ER-positive subgroup. Although CCAT2 levels were overall not informative for LNP patients that had received adjuvant tamoxifen or an anthracycline-containing regimen, for those LNP patients that had specifically received adjuvant $\mathrm{CMF}$ (cyclophosphamide, methotrexate, and 5-fluorouracil (5'FU)), increasing levels of CCAT2 were associated with shortened $\operatorname{MFS}(P=0.02)$ and OS $(P=0.004)$. Associations of CCAT2 levels with patient and tumor characteristics for these LNP patients $(n=134)$ that received adjuvant CMF are shown in Supplementary Table 2.

\section{Univariate and multivariate analysis for MFS}

To further investigate the independent relationship of CCAT2 with prognosis for the LNP patients that had received adjuvant $\mathrm{CMF}$, we have extended our previous patient group [12] with 13 new patients, which included 5 new LNP primary BC patients which received systemic adjuvant $\mathrm{CMF}$, and reanalyzed the data based on the most updated clinical information available for these patients. We therefore have redone the Cox univariate analyses for MFS as a function of CCAT2 expression levels in these LNP primary BC patients which received systemic adjuvant $\mathrm{CMF}$. To visualize the prognostic value of CCAT2 in Kaplan-Meier curves, we divided CCAT2 expression into 4 parts (negative, low, intermediate, and high, as based on the quartile levels of all 997 tumors) (Supplementary Fig. 3) for the 134 LNP primary BC patients that received systemic adjuvant $\mathrm{CMF}$. In these updated analyses, the upper $25 \%$ (high levels) of CCAT2 were significantly associated with MFS (HR 2.44, $P=0.011$ ) (Table 2 and Table 3).

Next, CCAT2 was also separately introduced to the base multivariate model that included the factors age, menopausal status, nodal status, tumor size, grade, ER and PR. Expression levels of CCAT2 also contributed significantly to the multivariate model for MFS in these LNP patients that had received adjuvant CMF (HR 2.25, $P=0.033$ for the upper vs. the lowest group) (Table 3 ).

\section{CCAT2 RNA, but not the SNP rs6983267 modulates cell migration and chemosensitivity in vitro}

We next aimed to explore in vitro the biology behind the results we obtained from the EMC patients cohort and for this purpose we cloned CCAT2 in a retroviral expression vector and transfected MDA-MB-231, a basallike BC cell line (endogenous rs6983267 TT genotype). We generated CCAT2 overexpressing clones that distinctively overexpress the two alleles $(\mathrm{G}$ and $\mathrm{T})$ of the SNP rs6983267, for assessing their individual impact onto cell migration and chemoresistance. High levels of the CCAT2 transcript induced a higher migratory potential of the cells independent of the genotype. We observed a 30\% increase in migration for CCAT2 G-overexpressing cells $(P=0.0195)$, while $C C A T 2$ T-overexpressing cells revealed a $70 \%$ increase $(P<0.0001)$ compared to the control cells (Fig. 3a, upper panel), simultaneously suggesting a dosedependent effect (Fig. 3a, lower panel). To further confirm the result, we transiently transfected MDA-MB-436 cells, also an ER-negative basal-like BC cell line (endogenous rs6983267 TT genotype), but with much lower levels of endogenous CCAT2 (Fig. 1c), with the $\mathrm{G}$ and T CCAT2 pcDNA 3.1 vectors and performed migration assays. While CCAT2 overexpressing MDA-MB-436 G cells migrated significantly more $(P=0.046)$ compared to control cells, the migration of MDA-MB-436 T cells increased compared to control cells, but not statistically significant $(P=0.192)$. However, the migration and RTqPCR results taken together suggest that the $G$ allele could induce a stronger migratory phenotype in this cell line than the T allele (Fig. 3b).

Considering that the clinical data analysis disclosed a significant correlation between the expression of CCAT2 and the MFS and OS of patients who received adjuvant CMF chemotherapy, we sought to determine whether these results are reproducible in vitro and whether the two alleles would modulate differently the chemosensitivity of the cells. Therefore, 3-[4,5-dimethylthiazol-2-yl]2,5-diphenyltetrazolium bromide (MTT) assays were performed to determine the viability of MDA-MB-231 CCAT2 clones treated with the DNA-damaging agent 5'FU, one of the components of CMF. Three different drug concentrations were administrated and 120 hours after treatment, the chemosensitivity was assessed. For all the drug concentrations, both the $\mathrm{G}$ and the $\mathrm{T}$ CCAT2 clones displayed significantly lower chemosensitivity compared to the control cells (Fig. 3c).

\section{DISCUSSION}

The objective of this study was to determine the prognostic value of CCAT2, a long non-coding RNA recently characterized by our group and located in a highly conserved genomic region [12]. Although, CCAT2 is overall overexpressed in BCs in two out of three patients sets, having the highest expression in LNN disease, its expression levels are clinically informative solely for a subgroup of BC patients, namely for patients with LNP disease that have received adjuvant CMF chemotherapy. This indicates that $C C A T 2$ is not a pure prognostic marker for BC progression, but for a particular subgroup (LNP, CMF treated patients) the expression level of CCAT2 may predict metastasis and poor survival, similar to the bonefide BC-specific lncRNA, HOTAIR [21]. Moreover, for the LNN group we found not only a positive correlation between $8 \mathrm{q} 24$ amplification and CCAT2 expression, but 
also a significant inverse correlation of $C C A T 2$ levels with ESR 1 and PGR levels. The ESR1 and PGR are essential predictive markers for $\mathrm{BC}$, as $E R S 1$ positive $\mathrm{BCs}$ are known to have a better prognosis and to respond to endocrine therapy. Consequently, this implies that LNN breast cancer patients having elevated levels of CCTA2 might not benefit from endocrine therapy.

On the other hand, contrary to our expectations we did not observe any correlation with the rs6983267 genotypes for neither of our patient groups and also our in vitro assays did not show any differences between the two genotypes. Of note, the SNP rs6983267 has been associated with risk of developing prostate and colon cancer in previous studies [15-17], as well as inflammatory breast cancer (IBC) [19], however, because our study groups were not selected to include a substantial number of IBC patients, this might be interesting to explore. All together, these data and the recently published ones from our group in CRC [12], support the concept that CCAT2 and rs6983267 are mainly associated with CRC and might be of interest for a specific sub group of BC.

More specifically, CCAT2 appears to be involved in a pathway explicitly used by non-anthracyclines. In accordance with this hypothesis, our in vitro chemosensitivity assays revealed increased resistance to 5'FU treatment for cells overexpressing CCAT2 with both $\mathrm{G}$ and T RNA allele compared to the control cells. Similar results were obtained when examining the migration potential of CCAT2 overexpressing cells in vitro. In both cellular models, MDA-MB-231 and MDA-MB-436, high $C C A T 2$ levels upregulated cell migration. Taken together, the results suggest $C C A T 2$ modulates in vitro migration and chemoresistance in a SNP-independent fashion. The molecular mechanism driving this regulation is still unclear. We speculate a possible involvement of $M Y C$ for the observed metastatic phenotype of high CCAT2 cells, in light of our previous findings in colon cancer [12] and of the documented presence of a large chromatin-loop bringing the SNP rs6983267 in the vicinity of the $M Y C$ oncogene in two IBC cell lines (SUM149 and SUM190). On the other hand, the increased chemoresistance of the CCAT2 overexpressing cells may not be mediated by $M Y C$, considering recent reports [22, 23], but rather by $T C F 4 / \beta$-catenin signaling. Our group has recently exposed the reciprocal regulatory mechanism between $C C A T 2$ and the Wnt pathway and furthermore, various studies have shown a positive correlation of TCF4/ $\beta$-catenin expression with chemoresistance to 5' FU, mostly in colon cancer, but also in BC [24-26]. Nonetheless, additional functional studies are required for complete understanding of the mechanisms.

In conclusion, our results suggest that $C C A T 2$ may represent a valuable predictive marker of clinical outcome (shorter MFS and OS) for a specific subgroup of BC patients, for which high levels of this long non-coding RNA will indicate that these patients will not benefit from
CMF adjuvant chemotherapy.

\section{MATERIALS AND METHODS}

\section{Patients.}

The Erasmus Medical Center (EMC) patient cohort. A protocol for studying biological markers associated with disease outcome was approved by the medical ethics committee of the Erasmus MC Rotterdam, The Netherlands (MEC 02.953). The study, for which written consent was not required, was performed in accordance with the Code of Conduct of the Federation of Medical Scientific Societies in the Netherlands (http://www.federa. org). To avoid bias, tumors were selected from the tumor bank at the Erasmus Medical Center (Rotterdam, The Netherlands) by processing all available frozen tumor samples from female patients with $\mathrm{BC}$ who entered the clinic during 1979-2000 from whom detailed clinical follow-up was available. Control normal breast tissue was collected from 15 cancer patients that either underwent prophylactic mastectomy $(n=5)$ or in which the breast tissue was removed at a distance from the primary tumor $(n=10)$. Further inclusion criteria for the BC tissues were as follows: $>100 \mathrm{mg}$ frozen tissue available, invasive $\mathrm{BC}$, no previous other cancer (except basal cell skin cancer or cervical cancer stage $\mathrm{Ia} / \mathrm{Ib}$ ), no 2 nd primary breast tumor at first relapse, adjuvant treatment for the lymph node positive (LNP) patients, no adjuvant systemic treatment for the lymph node negative (LNN) patients. Of the remaining samples, $8 \%$ were excluded because of poor RNA quality and $18 \%$ because the genomic DNA contamination was considered too high to guarantee correct evaluation of the non-intron spanning (monoexonic) CCAT2 gene (see also below).

The remaining 997 patients were treated either with breast-conserving surgery $(48 \%)$ or with modified mastectomy (52\%). Six hundred seventy-five patients $(68 \%)$ received adjuvant radiotherapy. All 376 LNP patients included in this study were treated with adjuvant systemic therapy, of whom 168 received hormonal therapy, 188 chemotherapy, and 20 combination therapy. Four hundred sixty-six patients (47\%) developed a distant metastasis and count as events in the analysis for metastasis-free survival (MFS). Fifty-eight patients died without evidence of distant metastasis and were censored at last follow-up in the analysis of MFS. Three hundred eighty-one patients $(38 \%)$ died after a previous relapse. Thus, 439 patients (44\%) were counted as events in the analysis of overall survival (OS). Tumor staging was according to the Union Internationale Contre le Cancer (UICC) tumor node metastasis classification [27]. Wherever possible, the study has been reported in line with the Reporting Recommendations for Tumor Marker 
Prognostic Studies guidelines [28]. Other relevant patient and tumor characteristics are listed in Table 1.

The Oncology Institute Cluj-Napoca (OICN) patient and control cohorts. Fifty-six individuals enrolled in the study, with ages between 30 and 67 , gave their written consent for sample collection and the molecular analysis and the study was approved by the Institutional Research Ethics Committee. The samples were collected between November 2008 and March 2013. BC diagnosis was confirmed by mammography or ultrasound with tumors over $3 \mathrm{~cm}$ diameter. Pathology analysis and staging was done according to American Joint Committee on Cancer (AJCC) criteria. ER, PR and Her2/neu status was analyzed by immunohistochemistry (IHC). Patients with Her2/neu 2+ were tested for gene amplification with chromogenic in situ hybridization (CISH) for validation. The patient's cohort included tumors with one positive receptor, except for one case, which was a triple negative breast tumor. All tumor samples were obtained from patients with ductal invasive carcinomas DCI $(n=30)$, two of them being combined: one with mucinous and one with cribriform carcinomas. After initial diagnosis, 25 patients had neoadjuvant chemotherapy, while 5 patients underwent sectorectomy or mastectomy immediately after initial diagnosis without neoadjuvant chemotherapy. Of these 25 patients, 13 patients followed neoadjuvant chemotherapy with epirubicin and cyclophosphamide (EC), 7 patients had cyclophosphamide and doxorubicin (AC) and 5 patients EC/AC (epirubicin/doxorubicin + cyclophosphamide) + (taxotere) TXT. As by August 2013 all patients were alive. Normal breast tissues as control samples $(n=26)$ were collected from patients diagnosed with fibrosis $(n=5)$, fibro adenomas $(n=4)$ and one phyllodes tumor, all collected by core biopsies or open excisional biopsy, or with invasive carcinomas $(n=16)$ collected by surgical procedures. All samples were snap frozen in liquid nitrogen immediately after collection and stored until RNA extraction.

\section{Tissue processing.}

The EMC patient cohort. The tissue processing and the estimation of invasive tumor cells was performed as previously described [29, 30]. Only specimens with at least $30 \%$ of the nuclei of epithelial tumor cell origin and distributed uniformly over at least $70 \%$ of the hematoxylin-eosin-stained tissue section area were included.

The OICN patient and control cohorts. Freshly harvested $\mathrm{BC}$ and non-cancer tissues were snap frozen in liquid nitrogen and disrupted using a mortar and pestle, until a fine powder was obtained.

\section{RNA isolation, cDNA synthesis and RT-qPCR assay.}

The EMC patient cohort. RNA isolation, cDNA synthesis, quantification of specific (m)RNA species, and quality control checks were done as described in detail [30]. Real-time RT-PCR (RT-qPCR) was performed in an ABI Prism 7700 Sequence Detection System (Applied Biosystems) and a Mx3000PTM Real-Time PCR System (Stratagene). PCR reactions were done in a final volume of $25 \mu \mathrm{l}$ containing cDNA synthesized from 5 to $15 \mathrm{ng}$ of total RNA, $330 \mathrm{nM}$ forward and reverse primer and $12.5 \mu 1$ Absolute $^{\mathrm{TM}}$ QPCR SYBR ${ }^{\circledR}$ Green (Abgene Limited, Epsom, UK). After 15 minutes of denaturation and activation of the Taq-DNA polymerase, PCR products were amplified in 35 cycles with 15 seconds of denaturing at $95^{\circ} \mathrm{C}, 30$ seconds of annealing at $62^{\circ} \mathrm{C}$ followed by data acquisition at $62^{\circ} \mathrm{C}$. To correct for possible contribution of traces of genomic DNA present in the total RNA samples, we measured the levels of an unrelated intronic sequence, $\mathrm{C} 17$ on chromosome $17 \mathrm{q} 25$ at the same PCR conditions and subtracted from the CCAT2 transcript levels. Specificity of the CCAT2 RNA transcript levels after correction for genomic DNA contribution with our quantitative $C 17$ genomic DNA PCR assay was further validated by RT-qPCR in a set of breast tumor samples before and after DNAse I treatment and by comparing levels measured in cDNA generated in the absence and presence of reverse transcriptase. When amplification rounds for CCAT2 exceeded 35 cycles, which was the case for $24 \%$ of the remaining samples, quantities were considered to be undetectable and were set at $50 \%$ of the expression level measurable at the detection threshold (0.00001). Primer sequences for ESR1, PGR, and the reference genes have all been described, as have the PCR reactions and validations performed to ensure PCR specificity [30]. To measure concentrations of the proliferation marker $\mathrm{Ki}-67$, we used the Hs00606991 m1 Assay-on-Demand from Applied Biosystems. For MYC we used the Hs00905030_m1 Assay-on-Demand. Concentrations of the target genes, expressed relative to our reference gene set [low-abundance reference gene hydroxymethylbilane synthase ( $H M B S$, formerly porphobilinogen deaminase, $P B G D)$, medium-abundance hypoxanthine phosphoribosyltransferase (HPRT1), and high-abundance $\beta 2$-microglobulin $(B 2 M)$ ], were quantified

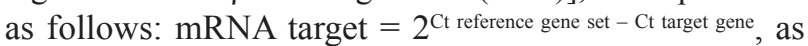
described [30]. All primer sequences are available in Supplementary Table 1.

The OICN patient and control cohorts. The samples were lysed using TriReagent and homogenized with a Rotor-stator homogenizer. RNA extraction was further carried according to classical phenol-chloroform extraction protocol. The total RNA was quantified with NanoDrop ND-1000 for quantity and Lab-on-Chip Bioanalizer for quality. Only samples with RIN greater 
than 7.5 were considered for further experiments. $1 \mu \mathrm{g}$ of total RNA were mixed with $2 \mu$ of DNase buffer, 1 $\mu l$ of Turbo DNAse (Ambion), $0.5 \mu$ l of RNAse Inhibitor (Roche) and RNase free $\mathrm{H}_{2} \mathrm{O}$ to a final volume of $20 \mu \mathrm{l}$ and incubated for $30 \mathrm{~min}$ at $37^{\circ} \mathrm{C}$. The DNAse was inactivated for $5 \mathrm{~min}$ with $2 \mu \mathrm{l}$ of DNAse Inactivation Reagent, samples were centrifuged and the RNA was transferred to fresh tubes. Before proceeding with the cDNA synthesis, RNA integrity after DNAse treatment was confirmed as described above.

Eight $\mu$ of DNAse treated RNA was used for cDNA synthesis using Transcriptor FirstStrand cDNA synthesis kit (Roche) according to the manufacturer instructions. RNA was diluted to a volume of $11 \mu$ l and incubated with $2 \mu \mathrm{l}$ of Random hexamer primers at $65^{\circ} \mathrm{C}$ for 10 min to remove secondary structures. The cDNA synthesis mix consisted of $4 \mu \mathrm{l}$ of buffer, $2 \mu \mathrm{l}$ of dNTPs, $0.5 \mu \mathrm{l}$ of RNAse Inhibitor and $0.5 \mu \mathrm{l}$ of reverse transcriptase. The reverse transcription reaction was performed in a heated lid thermocycler for $10 \mathrm{~min}$ at $25^{\circ} \mathrm{C}$, followed by $30 \mathrm{~min}$ at $55^{\circ} \mathrm{C}$. The reverse transcriptase was inactivated by heating the samples at $85^{\circ} \mathrm{C}$ for $5 \mathrm{~min}$. Samples with the RNA only were treated in the same manner and used as negative controls. Real time RT-PCR was performed in a LightCycler 480 apparatus using LightCycler 480 DNA SYBR Green I Master (Roche) with a primer concentration of $0.4 \mu \mathrm{M}$ in a $10 \mu \mathrm{l}$ reaction as instructed by the manufacturer and $20 \mathrm{ng}$ of cDNA were added to the mastermix. The $\mathrm{C}_{t}$ values were assessed using the automated second derivative max analysis. For the samples that exceeded 35 cycles of amplification, $C C A T 2$ was considered not to be expressed. The primer sequences for CCAT2 were identical to the ones used for the EMC patient cohort. U6 and HPRT1 were used as reference genes and the primer sequences are found in Supplementary Table 1 . Results were analyzed using the $2^{\text {-deltaCt }}$ method.

\section{Copy number alterations.}

Genomic DNA from 313 primary breast tumors LNN BC patients, from which 226 are included in this study to correlate copy number with CCAT2 mRNA expression, was hybridized to Affymetrix GeneChip@ Human 100K SNP Arrays as described before [31]. The median of the mean copy numbers computed from each SNP's interquartile copy number estimates of the 313 breast tumors was 2.1 , consistent with the general assumption that the majority of the genome is diploid. The DNA copy numbers for 12 SNP loci covering chr8:128,443,462-128,487,117 in the human genome were analyzed to identify samples whose copy number alterations (CNAs) were informative for gain, which was set at 1 unit gain over the diploid copy number of 2.1 , in this $8 \mathrm{q} 24$ region.

\section{Tissue microarray (TMA).}

Tissue specimens were obtained at the University of Texas, MD Anderson Cancer Center (MDACC) from women prospectively enrolled into LAB 08-0700, a blood and tissue based study examining biomarkers of breast cancer risk. This study enrolls women with a breast cancer diagnosis OR women with mammographic abnormality undergoing stereotactic biopsy. Paraffin embedded tissue blocks from either the surgical specimen (cancer patients) or stereotactic biopsy (non-cancer controls) were selected for the creation of tissue microarrays. For each case, up to $5,1 \mathrm{~mm}$ cores were transferred to a TMA block. After processing, unstained slides from the TMA block were used for the in situ hybridization as detailed below. Approval for this study was obtained from the institutional review board of MDACC.

\section{In situ hybridization (ISH).}

TMA slides were incubated with either a doubleDIG-labeled CCAT2 probe or control U6 snRNA probe (Exiqon) and detected as previously described [12].

\section{Cell culture.}

Specifics of the breast cancer cell line panel used at EMC to evaluate the expression of CCAT2 RNA have been described [32]. Human BC MDA-MB-231 and MDA-MB-436 cell lines used for the in vitro manipulation experiments were obtained from the American Type Culture Collection and grown as suggested by the supplier. Cells were cultured at $37^{\circ} \mathrm{C}$ in $5 \% \mathrm{CO}_{2}$. All cell lines were validated using STR DNA fingerprinting.

\section{Virus production.}

The stable MDA-MB-231 cells for overexpressing CCAT2 were prepared as previously described [12]. Briefly, the CCAT2-containing genomic region was amplified with genomic DNA with $P f u$ polymerase (Invitrogen) and cloned it into the pMX vector (Cell Biolabs). The CCAT2-containing retrovirus was then produced in 293 GP2 cell lines and the virus-containing supernatant was used to infect MDA-MB-231 cells. After infection, MDA-MB-231 cells were grown in complete media containing puromycin $(1 \mu \mathrm{g} / \mathrm{ml})$.

\section{Plasmid production and transient reverse transfection.}

The same sequences as used for the $\mathrm{pMX}$ retrovirus were cloned into a pcDNA 3.1 vector (Invitrogen) [12] 
and these vectors were further used for transient reverse transfection. Briefly, the transfection mix was prepared using Lipofectamine2000, according to the manufacturer's protocol for a final concentration of $50 \mathrm{nM}$ plasmid/ well. During the incubation period for forming the transfection complex, the cells were prepared at 80$90 \%$ confluence and added to the transfection mix at the end of the incubation period. After 24 hours cells were harvested, a part was further used for migration assay and the remainder was used for assessment of transfection efficiency by RT-qPCR.

\section{In vitro migration assay.}

Migration assay was performed as previously described [12]. Briefly, $100 \mu \mathrm{l}$ of serum-free media containing the cells (60 000 cells/insert for MDA-MB-436 and 55000 cells/insert for MDA-MB-231) were seeded onto the top of gelatin-coated insert and $500 \mu \mathrm{l}$ of media with serum was added to the bottom well. Cells were left to migrate 8 hours for MDA-MB-231 and 20 hours for MDA-MB-436, the optimum migration conditions for these cell lines, respectively. The cells that migrated to the bottom of the well were fixed, stained and counted using a microscope. For each well, 6 different fields were counted and the average number of cells was determined. The experiments were performed in triplicates.

\section{MTT (3-[4,5-dimethylthiazol-2-yl]-2,5- diphenyltetrazolium bromide) assay.}

In vitro chemoresistance to 5 'Fluorouracil (5' $\mathrm{FU}$ ) of MDA-MB-231 CCAT2 clones was assessed by MTT. Briefly, cells were plated 24 hours prior to treatment in 96 well microculture plates. After cells were adherent, 3 different doses of the drug were added to the supernatant without medium change. After 120 hours, the MTT reagent (Sigma) was added to each well and incubated for 3 hours at $37^{\circ} \mathrm{C}$. The optical density (OD) was read at 570 $\mathrm{nm}$ on a microplate spectrophotometer and growth values $(\%)$ were calculated as followed $\left(\mathrm{OD}_{\text {treated cells }} / \mathrm{OD}_{\text {untreated cells }}\right)$ $\mathrm{x} 100$. The experiments were performed in quadruplicate.

\section{Statistics.}

All the results derived from the in vitro experiments were expressed as the mean \pm SD for at least two separate experiments in triplicate or quadruplicate. For correlations with in vitro findings, data analysis was performed with SPPS and GraphPad Prism software. For correlations with clinical data, the STATA statistical package, release 12 (STATA Corp.) and SPSS 20.0 were used. The Shapiro-Wilk test was applied to verify if CCAT2 expression follows a normal distribution. Accordingly, $t$-test, respectively ANOVA test (depending on the number of groups considered) or the nonparametric test Mann-Whitney-Wilcoxon, respectively Kruskal-Wallis was applied to assess the relationship between CCAT2 expression and other characteristics. The strengths of the associations between continuous variables were tested with the Spearman rank correlation $\left(r_{s}\right)$. Variables were either log-transformed or Box-Cox-transformed to reduce the skewness. Because even after these transformations CCAT2 RNA levels were not normally distributed in the $\mathrm{n}=997$ clinical BC sample set (Fig 1d), clinical evaluations were performed after dividing CCAT RNA levels into 4 equally sized groups, thus also taking into account the $24 \%$ samples with undetectable levels of CCAT2. The prognostic values of the clinical and biological variables were tested with MFS and OS as the endpoint in the univariate, multivariate, and interaction analyses, with the use of the Cox proportional hazards model. The hazard ratio (HR) and its $95 \%$ confidence interval (CI) were derived from these results. We used Kaplan-Meier survival plots and log-rank tests for trend to assess the differences in time of the predicted high and low risk groups of patients. All tests were 2-sided, and $P<0.05$ was considered statistically significant.

\section{ACKNOWLEDGEMENTS}

Dr Calin is The Alan M. Gewirtz Leukemia \& Lymphoma Society Scholar. He was supported also as a Fellow at The University of Texas MD Anderson Research Trust, as a University of Texas System Regents Research Scholar and by the CLL Global Research Foundation. Work in Dr. Calin's laboratory is supported in part by the NIH/NCI (CA135444), a Department of Defense Breast Cancer Idea Award, Developmental Research Awards in Breast Cancer, Ovarian Cancer, Brain Cancer, Prostate Cancer, Multiple Myeloma, Leukemia (P50 CA100632) and Head and Neck (P50 CA097007) SPOREs, a SINF MDACC_DKFZ grant in CLL, a SINF grant in colon cancer, the Laura and John Arnold Foundation, the RGK Foundation and the Estate of C. G. Johnson, Jr. Dr. Berindan-Neagoe was financed by a POSCCE grant (709/2010) entitled Clinical and Economical Impact of Proteome and Transcriptome Molecular Profiling in Neoadjuvant Therapy of Triple Negative Breast Cancer (BREASTIMPACT). Dr Redis was financed by a POSDRU grant (88/1.5/S/56949) entitled 'Proiect de reforma a doctoratului in stiinte medicale: o viziune integrativa de la finantare si organizare la performanta stiintifica si impact'.

\section{REFERENCES}

1. Geng YJ, Xie SL, Li Q, Ma J and Wang GY. Large intervening non-coding RNA HOTAIR is associated with hepatocellular carcinoma progression. J Int Med Res. 2011; 
39(6):2119-2128

2. Gutschner $\mathrm{T}$, Baas $\mathrm{M}$ and Diederichs $\mathrm{S}$. Noncoding RNA gene silencing through genomic integration of RNA destabilizing elements using zinc finger nucleases. Genome Res. 2011; 21(11):1944-1954.

3. Hayami S, Kelly JD, Cho HS, Yoshimatsu M, Unoki M, Tsunoda T, Field HI, Neal DE, Yamaue H, Ponder BA, Nakamura Y and Hamamoto R. Overexpression of LSD1 contributes to human carcinogenesis through chromatin regulation in various cancers. Int J Cancer. 2011; 128(3):574-586.

4. Mourtada-Maarabouni M, Pickard MR, Hedge VL, Farzaneh F and Williams GT. GAS5, a non-protein-coding RNA, controls apoptosis and is downregulated in breast cancer. Oncogene. 2009; 28(2):195-208.

5. Poliseno L, Salmena L, Zhang J, Carver B, Haveman WJ and Pandolfi PP. A coding-independent function of gene and pseudogene mRNAs regulates tumour biology. Nature. 2010; 465(7301):1033-1038.

6. Calin GA, Liu CG, Ferracin M, Hyslop T, Spizzo R, Sevignani C, Fabbri M, Cimmino A, Lee EJ, Wojcik SE, Shimizu M, Tili E, Rossi S, Taccioli C, Pichiorri F, Liu X, et al. Ultraconserved regions encoding ncRNAs are altered in human leukemias and carcinomas. Cancer Cell. 2007; 12(3):215-229.

7. Staaf J, Jonsson G, Ringner M, Baldetorp B and Borg A. Landscape of somatic allelic imbalances and copy number alterations in HER2-amplified breast cancer. Breast Cancer Res. 2011; 13(6):R129.

8. Weigman VJ, Chao HH, Shabalin AA, He X, Parker JS, Nordgard SH, Grushko T, Huo D, Nwachukwu C, Nobel A, Kristensen VN, Borresen-Dale AL, Olopade OI and Perou CM. Basal-like Breast cancer DNA copy number losses identify genes involved in genomic instability, response to therapy, and patient survival. Breast Cancer Res Treat. 2012; 133(3):865-880.

9. Rennstam K, Ahlstedt-Soini M, Baldetorp B, Bendahl PO, Borg A, Karhu R, Tanner M, Tirkkonen M and Isola J. Patterns of chromosomal imbalances defines subgroups of breast cancer with distinct clinical features and prognosis. A study of 305 tumors by comparative genomic hybridization. Cancer Res. 2003; 63(24):8861-8868.

10. Yokota T, Yoshimoto M, Akiyama F, Sakamoto G, Kasumi F, Nakamura Y and Emi M. Frequent multiplication of chromosomal region 8q24.1 associated with aggressive histologic types of breast cancers. Cancer Lett. 1999; 139(1):7-13.

11. Courjal F and Theillet C. Comparative genomic hybridization analysis of breast tumors with predetermined profiles of DNA amplification. Cancer Res. 1997; 57(19):4368-4377.

12. Ling H, Spizzo R, Atlasi Y, Nicoloso M, Shimizu M, Redis R, Nishida N, Gafa R, Song J, Guo Z, Ivan C, Barbarotto E, De Vries I, Zhang X, Ferracin M, Churchman M, et al. CCAT2, a novel non-coding RNA mapping to 8q24, underlies metastatic progression and chromosomal instability in colon cancer. Genome Res. 2013.

13. Easton DF, Pooley KA, Dunning AM, Pharoah PD, Thompson D, Ballinger DG, Struewing JP, Morrison J, Field H, Luben R, Wareham N, Ahmed S, Healey CS, Bowman R, Meyer KB, Haiman CA, et al. Genomewide association study identifies novel breast cancer susceptibility loci. Nature. 2007; 447(7148):1087-1093.

14. Ghoussaini M, Song H, Koessler T, Al Olama AA, KoteJarai Z, Driver KE, Pooley KA, Ramus SJ, Kjaer SK, Hogdall E, DiCioccio RA, Whittemore AS, Gayther SA, Giles GG, Guy M, Edwards SM, et al. Multiple loci with different cancer specificities within the $8 \mathrm{q} 24$ gene desert. J Natl Cancer Inst. 2008; 100(13):962-966.

15. Haiman CA, Le Marchand L, Yamamato J, Stram DO, Sheng X, Kolonel LN, Wu AH, Reich D and Henderson BE. A common genetic risk factor for colorectal and prostate cancer. Nat Genet. 2007; 39(8):954-956.

16. Tomlinson I, Webb E, Carvajal-Carmona L, Broderick P, Kemp Z, Spain S, Penegar S, Chandler I, Gorman M, Wood W, Barclay E, Lubbe S, Martin L, Sellick G, Jaeger E, Hubner R, et al. A genome-wide association scan of tag SNPs identifies a susceptibility variant for colorectal cancer at 8q24.21. Nat Genet. 2007; 39(8):984-988.

17. Tuupanen S, Turunen M, Lehtonen R, Hallikas O, Vanharanta S, Kivioja T, Bjorklund M, Wei G, Yan J, Niittymaki I, Mecklin JP, Jarvinen H, Ristimaki A, DiBernardo M, East P, Carvajal-Carmona L, et al. The common colorectal cancer predisposition SNP rs6983267 at chromosome $8 \mathrm{q} 24$ confers potential to enhanced Wnt signaling. Nat Genet. 2009; 41(8):885-890.

18. Yeager M, Orr $\mathrm{N}$, Hayes RB, Jacobs KB, Kraft $\mathrm{P}$, Wacholder S, Minichiello MJ, Fearnhead P, Yu K, Chatterjee N, Wang Z, Welch R, Staats BJ, Calle EE, Feigelson HS, Thun MJ, et al. Genome-wide association study of prostate cancer identifies a second risk locus at 8q24. Nat Genet. 2007; 39(5):645-649.

19. Bertucci F, Lagarde A, Ferrari A, Finetti P, Charafe-Jauffret E, Van Laere S, Adelaide J, Viens P, Thomas G, Birnbaum D and Olschwang S. 8q24 Cancer risk allele associated with major metastatic risk in inflammatory breast cancer. PLoS One. 2012; 7(5):e37943.

20. Gong WF, Zhong JH, Xiang BD, Ma L, You XM, Zhang QM and Li LQ. Single Nucleotide Polymorphism 8q24 rs13281615 and Risk of Breast Cancer: Meta-Analysis of More than 100,000 Cases. PLoS One. 2013; 8(4):e60108.

21. Gupta RA, Shah N, Wang KC, Kim J, Horlings HM, Wong DJ, Tsai MC, Hung T, Argani P, Rinn JL, Wang Y, Brzoska P, Kong B, Li R, West RB, van de Vijver MJ, et al. Long non-coding RNA HOTAIR reprograms chromatin state to promote cancer metastasis. Nature. 2010; 464(7291):10711076.

22. Schlotter CM, Vogt U, Bosse U, Mersch B and Wassmann K. C-myc, not HER-2/neu, can predict recurrence and 
mortality of patients with node-negative breast cancer. Breast Cancer Res. 2003; 5(2):R30-36.

23. Todorovic-Rakovic N, Neskovic-Konstantinovic Z and Nikolic-Vukosavljevic D. C-myc as a predictive marker for chemotherapy in metastatic breast cancer. Clin Exp Med. 2012; 12(4):217-223.

24. Kendziorra E, Ahlborn K, Spitzner M, Rave-Frank M, Emons G, Gaedcke J, Kramer F, Wolff HA, Becker H, Beissbarth T, Ebner R, Ghadimi BM, Pukrop T, Ried T and Grade M. Silencing of the Wnt transcription factor TCF4 sensitizes colorectal cancer cells to (chemo-) radiotherapy. Carcinogenesis. 2011; 32(12):1824-1831.

25. Lu X, Deng Q, Li H and Suo Z. Altered characteristics of cancer stem/initiating cells in a breast cancer cell line treated with persistent 5-FU chemotherapy. Exp Ther Med. 2011; 2(5):821-826.

26. Xie J, Xiang DB, Wang H, Zhao C, Chen J, Xiong F, Li TY and Wang XL. Inhibition of Tcf-4 induces apoptosis and enhances chemosensitivity of colon cancer cells. PLoS One. 2012; 7(9):e45617.

27. UICC. Classification of malignant tumors of the breast according to clinical stage published under the auspices of the Union Internationale contre le Cancer. J Chir. 1959; 78:576-581.

28. McShane LM, Altman DG, Sauerbrei W, Taube SE, Gion $\mathrm{M}$ and Clark GM. REporting recommendations for tumor MARKer prognostic studies (REMARK). Breast Cancer Res Treat. 2006; 100(2):229-235.

29. Sieuwerts AM, Look MP, Meijer-van Gelder ME, Timmermans M, Trapman AM, Garcia RR, Arnold M, Goedheer AJ, de Weerd V, Portengen H, Klijn JG and Foekens JA. Which cyclin E prevails as prognostic marker for breast cancer? Results from a retrospective study involving 635 lymph node-negative breast cancer patients. Clin Cancer Res. 2006; 12(11 Pt 1):3319-3328.

30. Sieuwerts AM, Meijer-van Gelder ME, Timmermans M, Trapman AM, Garcia RR, Arnold M, Goedheer AJ, Portengen H, Klijn JG and Foekens JA. How ADAM-9 and ADAM-11 differentially from estrogen receptor predict response to tamoxifen treatment in patients with recurrent breast cancer: a retrospective study. Clin Cancer Res. 2005; 11(20):7311-7321.

31. Smid M, Hoes M, Sieuwerts AM, Sleijfer S, Zhang Y, Wang Y, Foekens JA and Martens JW. Patterns and incidence of chromosomal instability and their prognostic relevance in breast cancer subtypes. Breast Cancer Res Treat. 2011; 128(1):23-30.

32. Hollestelle A, Peeters JK, Smid M, Timmermans M, Verhoog LC, Westenend PJ, Heine AA, Chan A, Sieuwerts AM, Wiemer EA, Klijn JG, van der Spek PJ, Foekens JA, Schutte M, den Bakker MA and Martens JW. Loss of E-cadherin is not a necessity for epithelial to mesenchymal transition in human breast cancer. Breast Cancer Res Treat. 2013; 138(1):47-57. 